\title{
Çevre Bilinci Eğitiminde Muş Alparslan Üniversitesi’nin Ders Müfredatı Üzerine Bir İnceleme*
}

\section{A Study on the Curriculum of Mus Alparslan University in Environmental Awareness Education}

\author{
Mahmut Özdemirkol ${ }^{\text {a,*** }}$ \\ Öğr. Gör., Kafkas Üniversitesi, Sosyal Bilimler MYO, Yönetim ve Organizasyon Bölümü, Yerel Yönetim Pr., 36000, Kars /Türkiye \\ ORCID: 0000-0003-4878-9947
}

\begin{tabular}{l} 
MAKALE BİLGİSİ \\
\hline Makale Geçmişi: \\
Başvuru Tarihi: 28 Kasım 2020 \\
Düzeltme Tarihi: 20 Aralık 2020 \\
Kabul Tarihi: 23 Aralık 2020 \\
\hline Anahtar Kelimeler: \\
Çevre Eğitimi \\
Çevre Bilinci \\
Muş Alparslan Üniversitesi
\end{tabular}

\section{ART ICLE INFO}

Article history:

Received 28 November 2020

Received in revised form 20 December 2020 Accepted 23 December 2020

\section{Keywords:}

Environmental Education

Environmental Awareness

Muş Alparslan University
ÖZ

Çevre eğitimi çevresel sorunların çözümü, sürdürülebilir kalkınma, doğal ve yapay çevrenin korunması ekseninde bilinçli insanların yetiştirilmesi hedefine dayanmaktadır. Bu yaklaşıma göre çevresel sorunların sebebini bilen, çevresel sorunlar karşısında tutum ve davranış geliştiren çevresine duyarlı bilinçli insanların yetiştirilmesi çevre eğitiminin temel hedefleri arasındadır. Çevre eğitiminde üniversitelerin üstleneceği rol önemlidir. Çevre bilinci ve duyarlılığı gelişmiş, çevresel sorunların farkında olan ve bunu bir tutum ve davranışa dönüştüren insanların yetiştirilmesi üniversitelerin çevresel eğitim amaçları arasında olmalıdır. Türkiye'de öğretmenler ve öğrenciler üzerinde yapılan çeşitli alan araştırmalarının sonuçları Türkiye'de çevre eğitiminin teorik bir bilginin ötesine geçemediği ve çevre eğitiminin yetersiz olduğunu göstermektedir. $\mathrm{Bu}$ çalışmada çevre eğitiminin teorik çerçevesi ifade edilmiştir. Muş Alparslan Üniversitesi'nin ders müfredatı incelenmiş ve üniversitenin çevre eğitimindeki durumu incelenmiştir.

A B S T R A C T

Environmental education is based on the goal of raising conscious people on the axis of solving environmental problems, sustainable development, and protection of natural and artificial environment. According to this approach, raising conscious people who know the cause of environmental problems and develop attitudes and behaviors against environmental problems are among the main objectives of environmental education. Universities play an important role in environmental education. It should be among the environmental education objectives of universities to raise people who have developed environmental awareness and sensitivity, are aware of environmental problems and turn this into an attitude and behavior. The results of the research done on various areas in Turkey where teachers and students go beyond a theoretical knowledge of environmental education in Turkey and demonstrate that insufficient environmental education. In this study, the theoretical framework of environmental education is expressed. The course curriculum of Muş Alparslan University was examined and the status of the university in environmental education was reached.

\section{Giriş}

Günümüz toplumunda en çok tartıșılan konuların başında "çevre" gelmektedir. Bugün genel kabul gören ve aynı zamanda Türkiye Çevre Yasası'nda benimsenen tanıma göre; çevre, insanların ve diğer canlıların yaşamları boyunca ilişkilerini sürdürdükleri ve karşılıklı olarak etkileşim içinde bulundukları fiziksel, biyolojik, toplumsal, ekonomik ve kültürel ortamdır (2872 Sayılı Kanun, Madde 2). Çevre sorunlarının sebeplerinin ve çözüm önerilerin neler olduğu üzerinde bir uzlaşma bulunmamaktadır. Çevre sorunlarının sebepleri hakkında bir uzlaşı olmamakla beraber çevre sorunları, doğaları gereği bir bütün oluşturmakta, öğeleri arasında sıkı bir bağ ve ilişki bulunduğu kabul edilmektedir. Çevre yazın alanında çevre sorunları temel olarak hava, su ve toprağın kirlenmesi

\footnotetext{
* Bu çalışma, 22-23 Ekim 2020 tarihlerinde Muş Alparslan Üniversitesinde düzenlenen II. Uluslararası Muş Sempozyumunda sözlü bildiri olarak sunulmuștur.

** Sorumlu yazar/Corresponding author.

e-posta:m.ozdemirkol@gmail.com
} 
olarak belirtilmektedir. $\mathrm{Bu}$ sorunların yanında uluslararası platformlarda gündeme gelen ve çeşitli politikalara zemin hazırlayan çevre sorunları ise doğal sera etkisinin bozulması, iklim değişikliği, küresel 1sınma, ozon tabakasının incelmesi olarak sayılabilir (Torunoğlu, 2014). Çevre sorunları çeşitli toplumsal, ekonomik, sosyal ve siyasal birçok yönü bulunmaktadır. Çevre sorunları özü itibariyle bir taraftan doğal varlıklara tehdit oluştururken diğer taraftan ise insan hayatı ve sağlığını tehlikeye düşürmektedir.

Çevre sorunlarının uluslararası alanda ilgi konusu olması yeni sayılır. 1960'lı yıllarla birlikte çevre sorunları toplumsal hareketlerin, çevreci örgütlerin, aktivist ve akademi dünyasının önemli bir teması haline gelmiştir. Çevre sorunları artık insanların sağlıklı yaşam alanlarını etkilemektedir. Diğer taraftan çevre sorunları artık yerel bir sorun olmayıp küresel bir olgu haline gelmiştir. Çevresel sorunların sonuçlarından bütün insanlar etkilenmektedir. "Yaşayacak başka bir dünya yok" sözü çevreci anlayışın ve ilginin haklı bir sloganı olmuş durumdadır.

Çevre ekseninde gerek uluslararası gerekse ulusal düzeyde gelişen politika demetleri, tavsiyeler, yasal ve kurumsal düzenlemelerin gerekli ve önemli olduğu açıktır. Bunların çevre sorunlarının çözümünde önemli katkısı olsa da amaçlanan hedeflere ulaşabilmesi için çevre bilincinin ve çevreye duyarlılığın geliştirilmesi gereklidir. Sağlıklı ve sürdürülebilir bir çevre hedefi çevre bilincinin geliștirilmesinden bağımsız değildir. Çevre bilincinin geliştirilmesi çerçevesinde üniversiteler önemli bir yer tutmaktadır. Üniversiteler bir taraftan bilimsel bilgi üretme merkezleriyken diğer taraftan binlerce insanın eğitim öğretim gördükleri yerlerdir. Başta öğretmenler olmak üzere bütün üniversite mezunlarının aldıkları bilgi, beceri ve davranışlarla hayatlarına devam etmektedirler. $\mathrm{Bu}$ nedenle üniversitelerde çevre eğitimi ve çevre bilincinin geliştirilmesi yani öğrencilerin çevreci bir tutum ve davranış geliştirmesi sürdürülebilir, sağlıklı bir çevre için önemli görülmektedir. Böyle bir eğitim üniversite eğitiminin bir parçası olarak görülmelidir. Bir bütün olarak eğitim öğretim kurumlarında çevre eğitimiyle çevre bilincinin artırılması gerekli olmakla beraber üniversitelerinse önemli bir rolü bulunmaktadır. Çünkü Türkiye'de her yıl üniversite kurumlarına artan sayıda öğrenci kayıt yapmaktadır. Örneğin 2018 yılında örgün öğretim programlarına yerleşen toplam aday sayısı 710.982 iken bu sayı 2019 yılında 753.461 olarak gerçekleşmiştir (YÖK, 2021:2). Bu nedenle üniversitelerin sahip olduğu potansiyel, çevre bilincinin geliştirilmesinde önem arz etmektedir.

Üniversiteler sosyal değişim, etkileşim, iletişim ve gelişmenin gerçekleştiği en önemli kurumlardan biridir. Gençler ile hayat arasında bir köprü oluşturmaktadırlar. Bu nedenle insan yaşamını daha iyi seviyelere taşımakta önemli bir basamak rolü olan üniversitelerin program ve bölümlerinde alansal eğitim ve öğretimin yanı sıra çevre eğitimine de ihtiyaç duyulmaktadır (Tufaner ve diğerleri, 2020:13). Çevre sorunlarının çözümünde ve çevresel sorunlarla mücadelede bilinçli insan yetiştirilmesi hedefi eğitimin bir parçası ve gerekliliği olmuş durumdadır. $\mathrm{Bu}$ önemine binaen çalışmada Muş Alparslan Üniversitesi ders müfredatı incelenerek üniversitenin çevre bilinci eğitiminde yaklaşımı bulgular üzerinden değerlendirilmiştir.

\section{Yöntem ve Uygulama}

Her araştırmanın bir amacı olduğu gibi bu çalışmanın amacı artan çevre sorunlarıyla mücadelede uluslararası düzeyde öne çıkan çevre eğitimi ve bilincinin önemini ortaya koymak ve Muş Alparslan Üniversitesi ders müfredatı üzerinden bahsi geçen üniversitede çevre eğitiminin durumunu ortaya koymaktır. Bulgular eşliğinde üniversitede çevre eğitiminin geliştirilmesi için öneriler geliştirmektir. Çalışmanın araştırma nesnesi Muş Alparslan Üniversitesi'nin sahip olduğu ders havuzu, ders müfredatı, derslerin dağılımı ve bu dersleri alan ya da almayan öğrenci sayılarının karşılaştırılması olmuştur.

Çalışmada üniversitenin sahip olduğu sekiz lisans programı, altı ön lisans programı ve iki enstitünün ders havuzu, ders programları ve öğrenci sayıları incelenmiştir. ${ }^{1} \mathrm{Bu}$ incelemeler sonucunda elde edilen bulgular yedi tabloda sunulmuştur. Elde edilen bulguları özetleyen bu tablolar öğrencide çevreye karşı duyarlılık, farkındalık ve davranış geliştirme amacını ifade eden çevre eğitimi hususunda Muş Alparslan Üniversitesi'nin durumu hakkında önemli bilgiler sunmaktadır. Aynı zamanda çevre eğitimi konusunda üniversite ders müfredatının hangi yönde geliştirilmesi veya değiştirilmesi gerektiği hususunda veriler sunmaktadır. Çalışmanın araştırma nesnesi olan ders müfredatı, ders programları, öğrenci sayıları, faaliyet ve stratejik planlar internet üzerinden erişime açık olan üniversitenin resmi web sitesinde yer alan "Bologna" sayfası ve ilgili programların dokümanları araştırmacı tarafindan incelenerek elde edilmiştir. Açılan çevre dersleri ve dersi alan öğrenci sayıları Öğrenci İşleri Daire Başkanlığı'ndan elde edilmiştir.

Çalışmada çevre bilinci eğitiminin çevre sorunlarının çözümünde önemli bir rolü olacağı üzerinde durulmuştur. $\mathrm{Bu}$ nedenle çevre sorunları çerçevesinde gelişen kuramsal tartışmalara girilmemiştir. Bu çerçevede çevre eğitimi ve bilincinin artan önemi üzerinde durulmuştur. Çevre eğitiminin neden önemli ve gerekli olduğu çevre eğitiminin gelişmesinde rol oynayan uluslararası belgeler ışığında ortaya konulmuştur. Çevre bilincinin uluslararası gelişiminde en önemli rolü olan ve çevre eğitiminin kavramsal gelişimine önemli katkıları olan başta Belgrad ve Tiflis Konferansları olmak üzere uluslararası belgeler ve literatür taramasıyla çalışmanın kavramsal temeli oluşturulmuştur. Muş Alparslan Üniversitesi'nin çevre eğitimi müfredatı incelenerek çevre bilincinin geliştirilmesinde üniversitenin sahip olduğu perspektif ortaya konulmuştur. $\mathrm{Bu}$ temelde bu çalışmada Muş Alparslan Üniversitesinin ön lisans, lisans ve enstitülerde yer alan seçmeli ve zorunlu dersler içerisinde çevre temalı

\footnotetext{
${ }^{1}$ Muş Alparslan Üniversitesi; 5662 Sayılı Yükseköğretim Kurumları Teşkilatı Kanununda ve Yükseköğretim Kurumları Öğretim Elemanlarının Kadroları Hakkında Kanun Hükmünde Kararname ile Genel Kadro ve Usulü Hakkında Kanun Hükmünde Kararnameye Ekli Cetvellerde Değişiklik Yapılmasına Dair Kanunun 29/05/2007 tarihinde Resmî Gazete'de yayımlanarak yürürlüğe girmesiyle kurulan 17 üniversiteden biridir. Muş Alparslan Üniversitesi bünyesinde; 8 lisans ( Eğitim Fakültesi, Fen Edebiyat Fakültesi, İktisadi ve İdari Bilimler Fakültesi, İslami İlimler Fakültesi, Mühendislik-Mimarlık Fakültesi, Sağlık Bilimleri Fakültesi, Spor Bilimleri Fakültesi ve Uygulamalı Bilimler Fakültesi), iki enstitü (Fen Bilimleri Enstitüsü ve Sosyal Bilimler Enstitüsü) ve altı ön lisans (Bulanık MYO, Malazgirt Meslek Yüksekokulu, Sağlık Hizmetleri MYO, Sosyal Bilimler MYO, Teknik Bilimler MYO ve Varto MYO) yer almaktadır.
} 
derslerin ağırlıklarının ne olduğu sorusuna cevap bulunmaya çalışılmıştır. Müfredatın çevre eğitimine katkısı anlaşılmaya çalışılmıştır. Elde edilen bulgular kavramsal çerçeve ekseninde değerlendirilmiş ve nihayetinde çevre eğitiminde müfredatın geliştirilmesi için öneriler sunulmuştur.

\section{3. Çevre Eğitimi ve Gelişimi}

Çevre sorunları esasen ekosistemin kendi kendisini düzeltme yeterliliği üzerinde özellikle insanların denge bozucu faaliyetleri sonucu oluşan bir olgudur. Yani doğanın kendi kendisine yeten dengesinin insan faktörüyle bozulması sonucu çevre sorunları oluşmaktadır. Nitekim insan faktörünün çevreye yaptığı bilinçsizce müdahaleler doğanın kendi kendisini denetleyen bütünlüğüne zarar vermektedir (Kışlalıoğlu ve Berkes, 1993:25). Çevre, çevre sorunları ve ekoloji üzerine çalışanlar çevrenin birbiriyle ilişkili bir takım ilkeleri olduğunu ifade ederler. Bu ilkeleri şöyle sıralamak mümkündür (Kışlalıoğlu ve Berkes, 1993); doğanın bütün olduğu, doğanın sınırlı olduğu, doğanın bir öz denetime sahip olduğu, doğanın çeşitliliğe sahip olduğu ve doğada hiçbir şeyin yok olmadığı. Bu ilkeler ekosistemin birbirinden bağımsız olmadığı ve ekosistemin bir bütün olduğuna işaret eder. Bu temelde ekosistem insan neslinin sürdürülebilirliğgi, sağlığı ve geleceği için önemli olup insanın da içinde olduğu bütüncül bir sistem olduğu ifade edilebilir. Ekosistemin bir parçasına zarar verildiğinde bahsi edilen ilkelerden dolayı diğer parçaları zarar görmektedir. Ekosistemin sürdürülebilirliği insan türünün geleceği, sağlığı ve refahı için gereklidir. $\mathrm{Bu}$ nedenle ekosistem yönetiminin ve korunmasının mevcut ve gelecek nesillerin sosyoekonomik, politik ve kültürel ihtiyaçlarını karşılarken, büyük ekolojik hizmetleri korumayı ve doğal kaynakları eski haline getirmeyi amaçlayan bir süreçtir (Nwachukwu, 2014:65). Bu süreç yönetiminde çevre eğitimi önemli bir rol oynamaktadır. Çevre eğitimiyle insanların duyarlılıklarında, tutumlarında ve bilgilerinde çevreci yönlerinin geliştirilmesi aynı zamanda çevre sorunlarının kaynağında çözülmesine de yarayacaktır. Nitekim çevre sorunlarının çözümünde etkili ve kalıcı çözümler, bu sorunlarla mücadele konusunda bilinçli bireyler yetiştirilmesi ile mümkün olur (Demircioğlu vd, 2015:171). Çevre bilinci oluşmuş, çevresel sorunların sebeplerini bilen ve buna yönelik bir davranış sergileyen bilinçli insanların yetiştirilmesi çevrenin korunması, iyileştirilmesi veya geliştirilmesine fayda sağlayacağı açıktır.

Çevre eğitimiyle insanların bilinçlendirilmesi, insanlarda farkındalık oluşturulması ve çevreye duyarlılıklarının artırılması gerekmektedir. Çevreye dönük olumsuzlukları önleme sadece hükümet politikalarına ve çıkartılacak yasal düzenlemelere bırakılamaz. Çevresel sorunların çözümü, çevresel değerlerin geliştirilmesi ve korunması için sadece toplumun tepesinden çözümler veya adımlara bağlanılması esasen vatandaşların pasifleşmesi ve çevresel sorunların kaynağında çözülememesi gibi sonuçlara sebep olabilir. Çözümü sadece merkeziyetçi bir yaklaşımda aramak vatandaşların katılımıyla çözüm geliştirme olanağı zarar görür. David Orr'un ifadesiyle çözümler sadece toplumun tepesinden beklenildiğinde ekolojik olarak yetkin bir topluma özel bir ihtiyaç oluşturulamayacaktır. Bu nedenle çevre eğitimi çoğunlukla eğitim kurumlarının müfredatlarında bir ekstra olarak kabul edilecektir, temel bir gereklilik veya tüm eğitim sürecini kaplayan bir unsur olarak görülmeyecektir (Orr,1992:24). Çevresel sorunların çözümünde salt merkeziyetçi bir yaklaşım çevresel sorunların çözümünde eksik kalacaktır. Çevreci yasal düzenleme veya politikanın amacına ulaşması ve bunların etkinliği gerçekte insanlarda var olan çevre bilincinin düzeyinden bağımsız değildir. Aynı şekilde hükümet politikaları ve yasaların sadece uluslararası diplomatik ilişkilerde bir gereklilik olmaktan çıkartılıp toplumsal bir talep haline gelmesi çevre bilinci gelişmiş vatandaşlar sayesinde olacaktır. Bütün bu nedenlerle ekolojik sorunlar sadece bilimsel ölçüm, idari eylem ve teknolojik tazminatla çözülemeyeceğinden, kirletenle başa çıkmak için 'ekolojik eğitim' gereklidir (Schleicher,1989:257). Bu temelde çevresine duyarlı, çevresel sorunların sebep ve sonuçları arasında bağlantı kurabilen çevreci bir tutuma sahip insanların yetiştirilmesi başka bir ifadeyle çevre sorunlarının kaynağı olan insan faktörünün eğitilmesi, duyarlılık ve farkındalığının artırılması çevre sorunsallarının çözümü ekseninde önem arz etmektedir.

Çevreye verilen zararların büyümesiyle birlikte özellikle 1960'ların sonlarından itibaren artmaya başlayan çevre bilinci ve duyarlılık nedeniyle Birleşmiş Milletler (BM) öncülüğünde gelişen çözüm arayışlarının ana temalarından birisi çevre eğitimidir. Çevre hususunda bir dönüm noktası olarak kabul edilen 5 - 16 Haziran 1972 tarihinde Stockholm'de gerçekleşen BM İnsan Çevre Konferansı aynı zamanda çevre eğitimi üzerinde durmasıyla önemli bir uluslararası belge niteliğindedir. $\mathrm{Bu}$ konferansta kabul edilen bildirgenin 19. maddesine göre çevre ile ilgili konularda eğitim, gençlerin yanı sıra yetişkinlerin de, yoksul kesime saygısı göz önünde bulundurularak, çevrenin korunmasında ve iyileştirilmesinde bireylerin, işletmelerin ve toplulukların sorumlu davranışlarının temelini genişletmek için esastır (United Nation, 1972:5). BM'nin çevre konusunda gerçekleştirdiği bu ilk konferanstan sonra gerçekleşen çevre konferanslarında çevre eğitimi üzerinde durulan ana temalar olmuştur. Çünkü Gro Harlem Brundtland'in ifadeleriyle eğitim kurumlarının halkın bilinçlendirilmesi ve politik değişimin yaratılmasındaki rolleri vazgeçilmezdir; teşvik edilen tavırlar, sosyal değerler ve özlemlerdeki değişiklikler, geniş eğitim kampanyalarına bağlı olacaktır (United Nations, 1987:16). Brundthland Raporu olarak bilinen BM Dünya Çevre ve Kalkınma Komisyonu'nun "Ortak Geleceğimiz" isimli raporunun nüfus ve insan kaynakları bölümünde çevre sorunları arasında nüfus mevzusu üzerinde de durmaktadır. Rapor sorunun sadece nüfus fazlalığında olmadığını ifade eder. Aynı zamanda insanların kaynaklarla ilişkisinin göz önünde tutarak 'nüfus sorunu'nun kısmen kaynaklara daha eşit erişim sağlamak için kitlesel yoksulluğu ortadan kaldırmaya yönelik çabalarla ve bu kaynakları yönetmek için insan potansiyelini geliştirmeye yönelik eğitimle ele alınması gerektiğini ifade etmektedir (United Nations, 1987:27). Rapor esasen birçok çevre sorununun çözümünde ve önerilen davranış, tutum, kurumsal geliştirme ve yasal düzenlemelerde eğitim boyutu üzerinde özellikle durmaktadır. Nitekim raporun başarısı çevre eğitiminden bağımsız olmadığı kabul edilmiştir. Konferans kalkınma bağlamında çevresel konuları ele alırken, özellikle genç neslin çevre eğitimini ve çevrenin değerine ilişkin farkındalığı artırmak için diğer önlemleri teşvik etmeyi öne çıkarmaktadır (United Nation, 1992: 154). 1992'de 
gerçekleșen Rio Konferansı olarak bilinen BM Çevre ve Kalkınma Konferansı Raporu'nda çölleşme, kuraklık gibi sorunlara karşı insanların bilincini ve bilgisini artırma amacıyla çevre eğitimi üzerinde durmaktadır. Bu temelde çevre eğitiminin ilk ve orta okul müfredatına entegrasyonu dahil olmak üzere, çölleşme ve kuraklıkla ilgili kamu bilincini ve bilgisini geliştirmek ve artırmak gerekliliğini ifade etmektedir (United Nation, 1992:167). Çiftçiler için, özellikle kadınlar için çevre eğitimi almak, kırsal nüfusun dağ ekosistemlerinin sürdürülebilir kalkınmasına ilişkin ekolojik sorunları daha iyi anlamasına yardımcı olacaktır (United Nation, 1992:172). BM tarafindan 2002'de gerçekleştirilen Johannesburg Sürdürülebilir Kalkınma Dünya Zirvesi Raporu'nda çevresel sorunların çözümü için eğitimin önemine vurgu yapmaktadır. Rapor ekonomik büyümenin yanı sıra sosyal kalkınma ve çevrenin korunması için bir temel oluşturmak adına insan kaynakları geliştirmenin gerekli olduğunu vurgumıştır (United Nation, 2002: 124).

BM'nin çevre ve bu çalışmanın konu edindiği çevre eğitimi hususunda bir diğer önemli adımı ise BM'ye bağlı bir program olan BM Çevre Programı (UNEP)'nı oluşturmuş olmasıdır. Belgrad Konferansı'nda (1975) çevre eğitiminin küresel düşünce ve yerel eylem gerektirdiği ve 'insan ile biyosfer arasındaki ilişki' üzerine odaklanılması gerektiği belirtildi. Kısa bir süre sonra (Münih konferansında) sosyal bilimlerin doğa bilimlerinin tek taraflı olgusal-işlevsel yorumundan kaçınmak için farklı çevre perspektiflerini koordine etmesi gerektiği vurgulanmıştır (Schleicher,1989:267).

Çevre eğitimi alanında temel politikaları belirlemek ve çerçeve çizmek adına UNEP ve UNESCO işbirliğiyle birçok çalışma yapılmıştır. $\mathrm{Bu}$ çalışmaların en önemlileri Belgrad ve Tiflis Bildirgeleridir. Özellikle Tiflis Konferansının Bildirgesi ve önerileri, çevre eğitiminin insan eğitiminde yerini alması için bir dönüm noktası teşkil etmektedir. $\mathrm{Bu}$ belgelerde ulusal ve uluslararası düzeyde çevre eğitiminin geniş çerçevesiyle birlikte niteliği, amaçları ve pedagojik esasları belirtilmektedir (Ünal ve Dimişkı, 1999:143). Çevre eğitiminin dünya çevresinin korunması ve iyileştirilmesinin yanı sıra dünya toplumlarının sağlıklı ve dengeli kalkınmasındaki önemli rolüne dikkat çekilen uluslararası en önemli belgeler arasında Tiflis Deklarasyonu bulunmaktadır. Tiflis Deklarasyonu, Konferansın iki tavsiyesiyle birlikte yerel, ulusal, bölgesel ve uluslararası olmak üzere tüm düzeylerde ve tüm yaşlarda çevre eğitimi için çerçeve ilkeler ve yönergeler oluşturmaktadır.

Çevre eğitimi söz konusu olduğunda çevre konusunda genel bilgilerin yanında insanlarda çevresel sorunların kaynaklarına ilişkin bilinç, farkındalık ve davranışsal değişimler oluşturması söz konusu olmalıdır. Çevrenin korunması ve iyileştirilmesi için bireylerin çevresel problemleri içselleştirmesi hedeflenmektedir (Tufaner ve diğerleri, 2020:13). Nihayetinde kirletenle başa çıkmak için çevre eğitimi gereklidir. Çevre eğitimi insan ve doğa arasındaki karşılıklı ilişkiye referanslarla başlamalıdır (Schleicher,1989:257). Çevre eğitimi insanlarda çevreye dönük farkındalığın artırılması, çevre hakkında sorumlu kararlar almak için gereken eleştirel düşünme, problem çözme ve karar verme becerilerini sağlayan eğitim çabalarını ifade eder (Nwachukwu, 2014:1). Yani Orr'un ifadesiyle çevre eğitimi insanların sadece konuşma şeklini değil; aynı zamanda onların yaşam şeklini de değiştirmelidir (Orr, 1992:26).

Çevre konusunda önemli bir yeri olan Belgrad Bildirgesi'nde çevre eğitiminin amaçları farkındalık, bilgi, tutum, beceriler, değerlendirme yeteneği ve katılım olmak üzere altı ana başlıkla ifade edilmektedir. Bildirge çevre eğitiminde öne çıkardığı bu altı amacı şöyle tanımlamaktadır (The Belgrad Charter, 1975):

Farkındalık: Bireylere ve sosyal gruplara çevre ve bununla bağlantılı sorunlara ilişkin bir farkındalık ve duyarlılık kazanmalarına yardımcı olmak.

Bilgi: Bireylerin ve sosyal grupların çevre ve bununla ilişkili problemleri ve insanlığın buradaki kritik derecede sorumlu varlığı ve rolü hakkında temel anlayış kazanmalarına yardımcı olmak.

Tutum: Bireylerin ve sosyal grupların sosyal değerlere, çevre için güçlü endişe duygularına ve çevrenin korunmasına ve iyileştirilmesine aktif olarak katılma motivasyonu kazanmalarına yardımcı olmak.

Beceriler: Bireylere ve sosyal gruplara çevre sorunlarını çözme becerilerini kazanmalarına yardımcı olmak.

Değerlendirme Yeteneği: Bireylerin ve sosyal grupların çevresel önlemleri ve eğitim programlarını ekolojik, politik, ekonomik, sosyal, estetik ve eğitimsel faktörler açısından değerlendirmelerine yardımcı olmak.

Katılım: Bireylerin ve sosyal grupların çevre sorunları ile ilgili sorumluluk duygusu geliştirmelerine yardımcı olmak ve bu sorunları çözmek için uygun eylemi sağlamak

Çevre eğitiminde yol gösterici ilkeler vardır. Çevre eğitimi bu ilkeler perspektifinde geliştirilmelidir. Çevre eğitimi aşağıdaki yaklaşım ve ilkelerle ele alınmalıdır (The Belgrad Charter, 1975; Tbilisi Declaration, 1977):

- Doğal ve yapay çevre ayrımı gözetmeksizin ekolojik, politik, ekonomik, teknolojik, sosyal, yasal, kültürel ve estetik gibi çevreyi bir bütün olarak ele almalıdır.

- Çevre eğitimi hem okul içinde hem de okul dişında yaşam boyu devam eden bir süreç olmalıdır.

- Çevre eğitimi yaklaşımı disiplinler arası olmalıdır.

- Çevre eğitimi bölgesel farklılıklara gereken önemi göstererek, başlıca çevre sorunlarını dünya bakış açısından incelemelidir.

- Çevre eğitimi mevcut ve gelecekteki çevresel durumlara odaklanmalıdır.

- Çevre sorunlarının önlenmesi ve çözülmesine aktif katılımı vurgulamalıdır.

- Çevre eğitimi tüm gelişme ve büyümeyi çevresel açıdan incelemelidir.

- Çevre eğitimi çevre sorunlarının çözümünde yerel, ulusal ve uluslararası işbirliğinin değerini ve gerekliliğini teşvik etmelidir.

- Çevre eğitimi öğrencilerin çevre sorunlarının semptomlarını ve gerçek nedenlerini keşfetmelerine yardımcı olmalıdır.

- Çevre eğitimi çevre sorunlarının karmaşıklığını ve dolayısıyla eleştirel düşünme ve problem çözme becerilerini geliştirmelidir. 
- Öğrencilerin öğrenme deneyimlerini planlamada rol almalarını sağlamalıdır.

Çevre eğitimi hususunda belirtilmesi gereken başka bir noktaysa çevre eğitiminin sürdürülebilir kalkınma ilişkisi çerçevesinde ele alan bir yaklaşımın gelişmiş olmasıdır. Çevre eğitiminin tarihi, çevreyle ilgili değişen endişeler ve buna bağlı sorunlar ile çevre eğitiminin tanımlanma ve teşvik edilme şekli arasında yakın bir bağlantı vardır (Tilbury, 1995:197). 1990'larda artan çevre ve kalkınma ilişkisi çevre eğitiminin içeriğini bu yönde değiştirmiştir. Ekonomik kalkınma ve çevrenin korunması arasında uzlaşma ihtiyacı, çevresel kaygılarla ilgili herhangi bir anlayışı sosyo-ekonomik ve politik bir bağlama yerleştirme ihtiyacı, çevre ve kalkınma endişelerini birleştirme ihtiyacı (Tilbury, 1995:197) sürdürülebilirlik bağlamında çevre eğitiminin 1990'lar sonrası perspektifi olmuştur.

Eğitimin sürdürülebilir kalkınma ilişkisi ekseninde gelişiyor olmasına şüpheyle yaklaşanlar da vardır. Onlara göre çevre eğitiminde sürdürülebilir kalkınma gündemi sorunludur. Şöyle ki sürdürülebilir kalkınma için eğitim bir ürün olarak görülmekte ve küreselleşen güçlerin taşıyıcısı olmaktadır (Jicling ve Wals, 2008:18). Bu eleştirileri göz ardı etmemek gerekmektedir. Ancak bu eleştiri, kaygı ve şüphelere rağmen çevre eğitiminin uluslararası platformların katkılarıyla daha görünür ve eğitimin önemli bir parçası haline geldiğini de unutmamak gerekmektedir.

\section{Bulgular ve Değerlendirme}

Muş Alparslan Üniversitesi ders müfredatları ve ders havuzları incelendiğinde çevre temalı derslerin çeşitli isimlerle seçmeli veya zorunlu dersler olarak okutulduğu görülmektedir. ${ }^{2}$ Tablo 1'de üniversitenin 2019-2020 eğitim öğretim yılında sekiz fakültenin öğrenci sayıları, sahip olduğu toplam ders sayısını ve bu dersler içinde sahip olunan çevre temalı ders sayılarını ifade etmektedir. ${ }^{3} \mathrm{Bu}$ bulgular bize lisans programları arasında karşılaştırmalı olarak çevre temalı derslerin genel durum içinde ağırlıklarını değerlendirme imkânı vermektedir.

Eğitim Fakültesi'nin ders havuzunda yer alan seçmeli ve zorunlu toplamda 874 ders arasında çevre temalı seçmeli veya zorunlu dört ders bulunmaktadır. ${ }^{4}$ Spor Bilimleri Fakültesi ders havuzunda yer alan seçmeli ve zorunlu toplamda 355 ders arasında çevre temalı bir ders

\footnotetext{
${ }^{2}$ Ders havuzunda Çocuk ve Çevre, İnsan Davranışları ve Sosyal Çevre, Çevre Koruma, Çevre Sağlığı, Çevre Sorunları ve Yönetimi, Yenilenebilir Enerji Kaynakları, Spor ve Çevre, Çevre Eğitimi, Çevre Biyolojisi, Çevre Felsefesi, Çevre Sosyolojisi, Enerji ve Çevre Ekonomisi, Çevre Hukuku, Enerji ve Çevre Ekonomisi, Enerji Tasarrufu, Çevre Sağlığı ve Atık Yönetimi, Kimyasal Tehlikeler, Radyasyon ve Radyasyondan Korunma, Çevre ve Toplum, Organik ve Sürdürülebilir Tarım ve Çayır Mera Yönetimi ve Islahı gibi isimlerle yer almaktadır.

${ }^{3}$ Tablo'da Uygulamalı Bilimler Fakültesine yer verilmemiştir. İlgili program alan olarak çevreyle doğrudan ilgilidir. Fakültenin sahip olduğu ders müfredatı her ne kadar çevre alanıyla doğrudan ilgili olsa da fakültenin öğrenci sayısının 2019-2020 eğitim öğretim yılında 19 olması müfredatının daha fazla öğrenciye ulaşması önünde engel olduğundan bahsi edilen fakülte tabloda değerlendirilmemiştir.

${ }^{4}$ Fen Bilgisi Öğretmenliğinde bir zorunlu (FAZ403 Çevre Eğitimi) ve bir seçmeli ders (FAS910Seç: Yenilenebilir Enerji Kaynakları); Sosyal Bilgiler Öğretmenliğinde bir seçmeli (SBS901Seç: Çevre Eğitimi) ve Sınıf Öğretmenliğinde bir zorunlu ders (SAZ102Çevre Eğitimi) yer almaktadır.
}

bulunmaktadır. ${ }^{5}$ Fen Edebiyat Fakültesi ders havuzunda yer alan seçmeli ve zorunlu toplamda 690 ders arasında dört çevre temalı ders bulunmaktadır. ${ }^{6}$ İktisadi ve İdari Bilimler Fakültesi ders havuzunda yer alan seçmeli ve zorunlu toplamda 263 ders arasında yer alan çevre temalı üç ders bulunmaktadır. $^{7} \quad$ Mühendislik-Mimarlık Fakültesi’nde sadece Bilgisayarlı Muhasebe Bölümü'nde bir seçmeli ders yer almaktadır. Fakültenin ders havuzunda yer alan seçmeli ve zorunlu toplamda 88 ders bulunmaktadır. Sağlık Bilimleri Fakültesi ders havuzunda yer alan seçmeli ve zorunlu toplamda 277 ders bulunmaktadır. $\mathrm{Bu}$ dersler arasında çevre temalı ders sayısı iki adettir. ${ }^{8}$ İslami İlimler Fakültesi ders havuzunda yer alan seçmeli ve zorunlu toplamda 242 ders bulunmaktadır. $\mathrm{Bu}$ fakültede çevre temalı herhangi bir ders bulunmamaktadır. Bunlarla birlikte Uygulamalı Bilimler Fakültesi çevre konusunda en çok derslerin bulunduğu fakültedir. Bitkisel Üretim ve Teknolojileri ve Hayvansal Üretim ve Teknolojileri olmak üzere fakültede iki bölüm bulunmaktadır. Fakültede Tarımsal Ekoloji, Zooloji, Çevre ve Toplum, Sürdürülebilir Hayvansal Üretim, Organik ve Sürdürülebilir Tarım, Çayır Mera Yönetimi ve Islahı, Organik Hayvan Yetiştiriciliği, Hayvansal Atık Yönetimi, Toprak Bilimi, Biyokimya, Bitki Koruma, Pestisitler Çevre ve İnsan Sağlığı, Organik ve Sürdürülebilir Tarım, Çayır Mera Yönetimi ve Islahı, Organik Tarımda Zararlı Mücadelesi gibi dersler çevre ekseninde öne çıkan dersler olmakla birlikte program özü itibariyle öğrencilerin çevreci değerlerle yetiştirilmesine uygundur.

\begin{tabular}{|c|c|c|c|c|}
\hline \multirow[t]{2}{*}{ Birim } & \multirow{2}{*}{$\begin{array}{l}\text { Öğrenci } \\
\text { Sayısı } \\
(2019-2020)\end{array}$} & \multicolumn{2}{|c|}{ Ders Sayısı } & \multirow{2}{*}{$\begin{array}{l}\text { Çevre } \\
\text { Dersleri } \\
\text { Sayısı } \\
(\mathbf{Z} / \mathbf{S}) \\
\end{array}$} \\
\hline & & Zor. & Seç & \\
\hline Eğitim Fakültesi & 1.247 & 403 & 471 & 4 \\
\hline $\begin{array}{l}\text { Bed. Eğt ve Spor YO (Spor Bilimleri } \\
\text { Fakültesi) }\end{array}$ & 420 & 151 & 204 & 1 \\
\hline Fen Edebiyat Fakültesi & 1.180 & 406 & 284 & 4 \\
\hline İktisadi ve İdari Bilimler Fakültesi & 491 & 129 & 134 & 3 \\
\hline İslami İlimler Fakültesi & 995 & 108 & 134 & - \\
\hline Mühendislik-Mimarlik Fakültesi & 117 & 49 & 39 & 1 \\
\hline Sağlik Bilimleri Fakültesi & 665 & 178 & 99 & 2 \\
\hline Uygulamalı Bilimler Fakültesi & (19) & $(127)$ & $(72)$ & \\
\hline Toplam & 5115 & 1424 & 1365 & 15 \\
\hline
\end{tabular}

Tablo 2'de üniversitenin 2019-2020 eğitim öğretim y1lında ön lisans programının öğrenci sayılarını, sahip olduğu toplam ders sayısını ve bu dersler içinde sahip olunan çevre temalı ders sayılarını ifade etmektedir. Lisans programlarında olduğu gibi bu bulgular bize ön lisans programının sahip olduğu ders havuzu içinde çevre temalı derslerin ağırlıklarını ve bölümler arasında karşılaştırıla bilinmesi imkânı tanımaktadır. Tablo 2'ye bakıldığında Teknik Bilimler Meslek Yüksekokulu'nda on yedi program

${ }^{5}$ İlgili ders Spor Yöneticiliği Bölümü'nde seçmeli (YSY905Spor ve Çevre) olarak bulunmaktadır.

${ }^{6}$ Biyoloji Bölümü'nde bir zorunlu (BİY218Çevre Biyolojisi); Felsefe Bölümü'nde bir seçmeli (FEL219 Çevre Felsefesi), Moleküler Biyoloji ve Genetik bölümünde bir zorunlu (MBG304Çevre Biyolojisi) ve Sosyoloji Bölümü'nde bir seçmeli (SOS348Çevre Sosyolojisi) ders yer almaktadır.

${ }^{7}$ İktisat Bölümü'nde bir seçmeli (İKT308 Enerji ve Çevre Ekonomisi), Siyaset Bilimi ve Kamu Yönetimi’nde iki seçmeli (KAY303Çevre Sorunları ve Yönetimi ve KAY412 Çevre Hukuku) ders yer almaktadır.

${ }^{8}$ İş Sağlığı ve Güvenliği Bölümü'nde bir seçmeli (İSG226SEÇ II: Enerji Tasarrufu) ve bir zorunlu ( İSG324Çevre Sağlığı ve Atık Yönetimi) ders yer almaktadır 
görülmektedir. Birimde 2019-2020 öğrenci sayısı 1046'dır. $\mathrm{Bu}$ programların on tanesinde çevre temalı seçmeli dersler bulunmaktadır. ${ }^{9}$ Meslek Yüksek Okulunun ders havuzunda yer alan zorunlu ve seçmeli toplam 621 ders içerisinde 11 seçmeli ders yer almaktadır. On üç programa sahip olan Sosyal Bilimler Meslek Yüksekokulu'nun 2019-2020 öğrenci sayısı 1004'dur. Birimin seçmeli ve zorunlu ders havuzunda bulunan toplam 528 ders içerisinde bir seçmeli ve bir zorunlu ders bulunmaktadır. ${ }^{10}$ Malazgirt Meslek Yüksekokulu beş program ve birimin ders havuzunda seçmeli/zorunlu toplamda 207 ders arasında sadece Çocuk Gelişimi programında "ÇGİ232 Çocuk ve Çevre " ismiyle yer alan bir seçmeli ders bulunmaktadır. 2019-2020 eğitim öğretim yllında 554 öğrenciye ev sahipliği yapan Sağlık Hizmetleri Meslek Yüksekokulu'nun ders havuzunda yer alan zorunlu ve seçmeli toplamda 187 ders arasında dört çevre temalı ders yer almaktadır. ${ }^{11}$ Bulanık Meslek Yüksekokulu 2019-2020 eğitim öğretim yılı verilerine göre 202 öğrenciye sahiptir. Ders havuzlarında yer alan zorunlu ve seçmeli toplamda 209 ders içerisinde altı çevre temalı ders yer almaktadır. ${ }^{12}$ Varto Meslek Yüksekokulu 20192020 eğitim öğretim yllı verilerine göre 112 öğrenciye ev sahipliği yapmaktadır. Birimin zorunlu ve seçmeli ders havuzunda toplamda 158 ders vardır. Bu derslerin üç tanesi çevre temalıdır. ${ }^{13}$

\begin{tabular}{|l|l|l|l|l|}
\hline Tablo 2: Muș Alparslan Üniversitesi Ön Lisans Verileri \\
\hline Birim & $\begin{array}{l}\text { Öğrenci } \\
\text { Sayısı } \\
\mathbf{( 2 0 1 9 - 2 0 2 0 )}\end{array}$ & \multicolumn{2}{|l|}{ Ders Sayısı } & Çevre \\
\cline { 3 - 5 } & Zorunlu & Seçmeli & $\begin{array}{l}\text { Dersleri } \\
\text { Z/S }\end{array}$ \\
\hline Teknik Bilimler MYO & 1046 & 492 & 129 & 11 \\
\hline Sosyal Bilimler MYO & 1004 & 442 & 86 & 2 \\
\hline Malazgirt MYO & 318 & 165 & 42 & 1 \\
\hline Sağlik Hizmetleri MYO & 554 & 124 & 63 & 4 \\
\hline Bulanık MYO & 202 & 149 & 60 & 6 \\
\hline Varto MYO & 112 & 111 & 47 & 3 \\
\hline Toplam & $\mathbf{3 2 3 6}$ & $\mathbf{1 4 8 3}$ & $\mathbf{4 2 7}$ & $\mathbf{2 7}$ \\
\hline
\end{tabular}

${ }^{9}$ Yenilenebilir Enerji Kaynakları" ismiyle seçmeli olan ders Elektrik, Elektronik Teknolojisi, İnşaat Teknolojisi, Otomotiv Teknolojisi, Raylı Sistemler İşletmeciliği, Raylı Sistemler Yol Teknolojisi ve Ulaştırma ve Trafik Hizmetleri programlarında birer seçmeli ders yer almaktadır. "Çevre Koruma" ismiyle yer alan seçmeli ders Gıda Kalite Kontrolü ve Analizi, Gıda Teknolojisi programı ve Süt ve Ürünleri Teknolojisi programların yer almaktadır.

${ }^{10} \mathrm{Bu}$ dersler sadece iki programın ders müfredatında vardır. Başka bir değişle birimde yer alan Çocuk Gelişimi (ÇGİ210 Çocuk ve Çevre) ve Yerel Yönetimler ( Çevre Sorunları ve Yönetimi) dışında herhangi bir programda çevre temalı bir ders bulunmamaktadır.

${ }^{11}$ Ameliyathane Hizmetleri'nde bir ders (AMH112SEÇ IV: Çevre Koruma), Çocuk Gelişimi'nde bir ders (ÇGí232 SEÇ IX: Çocuk ve Çevre), İlk ve Acil Yardım bir ders (İAY221 SEÇ: Çevre Koruma) ve Tıbbi Laboratuvar Tekniklerinde bir ders (TLT212 SEÇ: Çevre Sağlı̆̆ı) yer almaktadır.

${ }^{12}$ Birimde yer alan Acil Durum ve Afet Yönetimi'nde iki ders (ADY207Afetlerde Çevre Sağlığı Hizmetleri ve ADY206 Doğada Yaşam ve Hayatta Kalma), Cocuk Gelișimi Programında bir ders (CGP214 Cocuk ve Çevre), Sosyal Hizmetler Programında iki ders ( SHİ201İnsan Davranışları ve Sosyal Çevre I, SHİ202 İnsan Davranışları ve Sosyal Çevre II ), ve Laborant ve Veteriner Sağlı programında bir ders (LVS124SEÇ: Çevre Koruma) yer almaktadır.

${ }^{13}$ Birimin bünyesinde olan Optisyenlik programında bir ders ( OPT209 SEÇ: Çevre Koruma), Özel Güvenlik ve Koruma programında bir ders (ÖGK222, SEÇ: Çevre Koruma) ve Spor Yönetimi'nde bir ders (SPY214 SEÇ: Spor ve Çevre) yer almaktadır.
Çevre bilinci özü itibariyle insanoğlunun çevre sorunlarını algılamış olması, sorunların çözümü için emeğini ortaya koyması ve çevreye karşı olan sorumluluğunun farkına varmış olması olgunluğudur (Cansaran, 2014:70). Bu olgunluğa erișebilmek için ders müfredatlarında çevre temalı derslerin yeterli veya dengeli bir ağıllığının olması gerekmektedir. $\mathrm{Bu}$ dersleri öğrencilere aldırarak onların çevre sorunlarına karşı tutum ve davranış geliştirebilmesini, çevre bilgisini uygulamaya dönüştürebilmesini sağlamak gerekmektedir. $\mathrm{Bu}$, sadece ders sayısıyla geliştirilemeyip aynı zamanda bu derslerin tutum, davranış, beceri geliştirebilecek bir muhteva ve yöntemle işlenmesini de içerir. Ancak muhteva ve yöntemi tartışabilmek için öncelikle ders havuzunda çevre temalı derslerin dengeli bir dağılımının olması ve bu derslerin açılmış olması gerekir. Tablo 1 ve 2'de görüldüğ̈̈ gibi lisans ve ön lisans programlarının sahip olduğu havuz 4699 dersten oluşmaktadır. Bunlar içinde çevre temalı ders sayısı 42 'dır. Bazı bölümlerin havuzunda 1 tane ders bulunurken İlahiyat Fakültesi'nde ise çevre temalı bir ders bulunmamaktadır. Muş Alparslan Üniversitesi Uygulamalı Bilimler Fakültesi'nin dışında fakültelerin ders havuzunda yer alan 2789 seçmeli ve zorunlu ders içerisinde çevre temalı ders sayıs1 15 tanedir. Ön lisans programlarındaysa 1910 seçmeli ve zorunlu ders havuzu içerisinde seçmeli derslerin sayısı $27^{\prime}$ dir. Havuzda yer alan 42 çevre temalı derslerden 2019-2020 eğitim yılında tablo 3 ve 4 'te gösterildiği gibi bu derslerden sadece 29'unun açıldığı görülmektedir. Yani havuzda bulunan derslerin okutulması aşamasında çevre temalı derslerin sayısı daha da azalmıştır. Bu durumda öğrencilerin çevre dersi alma imkânı azalmış olacağından çevre eğitiminin ifade ettiğgi bilgilendirme, farkındalık oluşturma, tutum ve davranış geliştirme gibi hedeflere ulaşılması mümkün olmayacaktır. Çevre sorunları siyasal, ekonomik, toplumsal ve sosyal boyutları olan bir olgudur. Çevre sorunlarının çözümünde etkili ve kalıcı çözümler, bu sorunlarla mücadele konusunda bilinçli bireylerin yetiştirilmesi ile mümkün olur. Bu sebeple çevre bilincine sahip bireylerin yetişmesi için eğitimin her kademesinde çevre eğitimine önem verilmelidir (Demircioğlu vd, 2015:171). Muş Alparslan Üniversitesi eğitim müfredatının görünen tablosu olgunun önemi karşısında çevre eğitiminin gerekli yeterliliğe sahip olmadığını göstermektedir.

Tablo 3'de 2019-2020 eğitim öğretim yılında lisans programlarında açılan çevre dersleri ve bu dersleri alan öğrenci sayılarını göstermektedir. Bu verilere göre lisans programlarında ilgili eğitim öğretim yılında açılan çevre temalı ders sayıları dokuzdur. Bu dersleri 206 öğrenci almıştır. Tablo 5'de görüleceği üzere bu 206 öğrencinin 112'si eğitim fakültesi'nin öğrencileridir. Tablo 1 'de ifade edildiği gibi aynı eğitim öğretim yılında lisans programlarına kayıtlı öğrenci sayısıysa 5115'tir. 


\begin{tabular}{|l|l|l|l|}
\hline $\begin{array}{l}\text { Tablo 3: 2019-2020 Eğitim Öğretim Yıl } \\
\text { Acılan Lisans Cevre Dersleri }\end{array}$ \\
\hline Dersin Adı & Bölümü & Sınıf & $\begin{array}{l}\text { Öğrenci } \\
\text { Sayısı }\end{array}$ \\
\hline Çevre Felsefesi & Felsefe & 2 & 27 \\
\hline $\begin{array}{l}\text { Çevre Sorunları ve } \\
\text { Yönetimi }\end{array}$ & $\begin{array}{l}\text { Siyaset Biı. ve } \\
\text { Kamu Yön. }\end{array}$ & 3 & 29 \\
\hline Çev. Etki Değ (ÇED) & Biyoloji & 1 & 1 \\
\hline Çevre Bilimi & Fen Bilgisi Öğrt. & 3 & 18 \\
\hline Çevre Kimyası & Fen Bilgisi Öğrt. & 4 & 26 \\
\hline Çevre Eğitimi & Sınıf Öğrt. & 1 & 44 \\
\hline Çevre Eğitimi & Sos. Bilg. Öğrt. & 1 & 24 \\
\hline $\begin{array}{l}\text { SEÇIIII: Çevre } \\
\text { Sosyolojisi }\end{array}$ & Sosyoloji & 3 & 36 \\
\hline $\begin{array}{l}\text { Pestisitler Cevevre ve } \\
\text { İnsan Sağlığı }\end{array}$ & $\begin{array}{l}\text { Bitkisel Üretim } \\
\text { ve Teknolojileri }\end{array}$ & 2 & 1 \\
\hline Toplam & & & $\mathbf{2 0 6}$ \\
\hline
\end{tabular}

Tablo 4'de 2019-2020 eğitim öğretim y1lında ön lisans programlarında açılan çevre dersleri ve bu dersleri alan öğrenci sayıları görülmektedir. $\mathrm{Bu}$ verilere göre üniversitede bahsi edilen eğitim öğretim yılında açılan çevre temalı ders sayıları yirmi birdir. Bu dersleri 312 öğrenci almıştır. Tablo 2'de ifade edildiği gibi ön lisans programları aynı eğitim öğretim yılında 3236 öğrenciye sahiptir.

\begin{tabular}{|c|c|c|c|}
\hline Dersin Adı & Bölümü & Sinif & $\begin{array}{l}\text { Öğrenci } \\
\text { Sayısı }\end{array}$ \\
\hline İnsan Dav. ve Sosyal Cevre I & Sosyal Hizmetler & 2 & 20 \\
\hline Çevre Koruma & Optisyenlik & 2 & 16 \\
\hline İnsan Dav. ve Sosyal Çevre II & Sosyal Hizmetler & 2 & 18 \\
\hline Cocuk ve Cevre & Çocuk Gelişimi & $2 \mathrm{~A}$ & 22 \\
\hline Çocuk ve Çevre & Çocuk Gelişimi & 2-B & 22 \\
\hline Çocuk ve Çevre & Çocuk Gelişimi & 2 & 27 \\
\hline Cocuk ve Cevre & Çocuk Gelişimi & 2 & 18 \\
\hline Çevre Sağliğ & T1bb1 Lab. Teknikleri & 2 & 21 \\
\hline Çevre Sorunları ve Yönetimi & Yerel Yönetimler & 2 & 16 \\
\hline Cevre Sağlığ1 ve Atık Yönetimi & İș Sağlığ1 ve Güvenliği & 1 & 6 \\
\hline Çevre Koruma & Organik Tarım & 1 & 2 \\
\hline Çevre Koruma & G1da Teknolojisi & 1 & 8 \\
\hline Radyasyondan Korunma & İş Sağliğ1 ve Güvenliği & 2 & 4 \\
\hline Kimyasal Tehlikeler & İş Sağliğ1 ve Güvenliği & 1 & 8 \\
\hline Yenilenebilir Enerji Kaynakları & Elektrik & 1 & 20 \\
\hline Yenilenebilir Enerji Kaynaklar1 & Elektronik Teknolojisi & 1 & 6 \\
\hline Yenilenebilir Enerji Kaynakları & İnşaat Teknolojisi & 2 & 12 \\
\hline Yenilenebilir Enerji Kaynakları & Yap1 Denetim & 2 & 4 \\
\hline Yenilenebilir Enerji Kaynakları & Rayli Sis. Yol Tek. & 1 & 22 \\
\hline Yenilenebilir Enerji Kaynakları & Ray. Sis. İş1. & 1 & 18 \\
\hline Yenilenebilir Enerji Kaynakları & Ulaş. ve Trafik Hiz. & 1 & 22 \\
\hline Toplam & & & 312 \\
\hline
\end{tabular}

Tablo 3 ve 4'te ifade edilen bulgular 8351 öğrencinin olduğu eğitim öğretim yılında 518 öğrencinin çevre temalı bir ders aldığıdır. Yani her 10 öğrenciden 1'inden daha azı çevre temalı bir ders almaktadır. Öğrenciliği sırasında herhangi bir çevre dersi ile karşılaşmayacak öğrenciler vardır. Çevre duyarlılığı ve bilgisi arasında bir farklılık olduğunu çeşitli alan araştırmalarıyla ortaya konulmuştur. $\mathrm{Bu}$ çalışmaların ifadelerine göre çevre eğitimi dersi sayesinde öğrencilerin çevreye karşı tutum ve davranışlarında olumlu yönde değişiklikler meydana geldiği sonuçlar elde edilmiş̧ir (Erökten ve Durkan, 2010:1865; Karademir, 2016:14; Şahin vd, 2016:91; Kılıç, 2010:81; Atik ve Doğan, 2019:10; Oğuza vd 2011:38; Öztürk, 2019:76). Bu nedenle üniversitelerin eğitim planlamasında çevre eğitimi derslerinin yeterli düzeyde olması öğrencilerin çevreye karşı bilgi, bilinç ve duyarlılıklarının artmasına yardımcı olacaktır. Yapılan bir çalışmanın öğrenci ve velilerin geri dönüşüm konusunda dahi bilgi sahibi olmadığını ortaya koyması (Yücel ve Morgil, 1999: 81) çevre eğitiminin gereği ve önemine işaret etmektedir.
Yukarıdaki bulguların ifade ettiği gibi Muş Alparslan Üniversite mezunu olup hiçbir çevre dersi almayacak öğrenci sayısı yüzde 90'ın üstündedir. Hiçbir çevre eğitimi almayan insanların var olduğu ve bazı bölümlerde seçmeli dahi olsa herhangi bir çevre dersi olmadığı sonucuna varan başka alan çalışmaları (Selim vd, 2011:154; Erten, 2005: 93, Öztürk, 2019:77) ile bu çalışmanın bulguları örtüşmektedir. Bu veriler bir arada düşünüldüğünde çevre eğitimi konusunda alan araştırması yapılan üniversitelerin ve Muş Alparslan Üniversitesi'nin yeterli düzeyde olmadığ ifade edilebilir. Muş Alparslan Üniversitesi mezunlarının büyük bir bölümünün öğrenim süreçlerinde hiçbir çevre dersi almayacak olması çevre eğitimi hususunda müfredatı geliştirme ve değiştirme gerekliliğine işaret eder. $\mathrm{Bu}$ gereklilik aynı zamanda Türkiye'nin üyesi olduğu BM belgelerinin de çevre eğitimi hususunda beklentisidir.

Tablo 5'de Muş Alparslan Üniversitesi Eğitim Fakültesi’nde 2019-2020 eğitim öğretim yılında açılan çevre temalı dersler ve bu dersleri alan öğrenci sayılarını göstermektedir. $\mathrm{Bu}$ tabloya göre ilgili eğitim öğretim yılında eğitim fakültesinde 4 adet çevre temalı ders açıldığı görülmektedir. Bu dersleri alan toplam öğrenci sayısıysa 112 olmuştur. Aynı eğitim öğretim yılında eğitim fakültesinin öğrenci sayısı Tablo 1'de görüldüğü gibi 1247'dir. Eğitim Fakültesinin 874 seçmeli ve zorunlu ders havuzunda sadece 4 çevre temalı ders bulunmaktadır. $\mathrm{Bu}$ dersler fakültede bulunan sekiz bölüm içerisinden sadece üç bölümde (Fen Bilgisi Öğretmenliği, Sınıf Öğretmenliği ve Sosyal Bilgiler Öğretmenliği) yer almaktadır. Yani eğitim fakültesinde yer alan beş bölümde çevre temalı herhangi bir ders görülmemektedir. $\mathrm{Bu}$ bulgular sonucunda ifade edilebilir ki eğitim fakültesinden mezun olacak öğrencilerin çok büyük bir kısmı hiçbir çevre dersi almadan öğretmen adayı olmaya hak kazanacaklardır.

\begin{tabular}{|c|c|c|c|}
\hline \multicolumn{4}{|c|}{$\begin{array}{l}\text { Tablo 5: Eğitim Fakültesi 2019-2020 Eğitim Yılı Açlan } \\
\text { Cevre Dersleri }\end{array}$} \\
\hline Dersin Adı & Bölümü & Sinff & $\begin{array}{l}\text { Dersin } \\
\text { Öğrenci } \\
\text { Say. }\end{array}$ \\
\hline Çevre Bilimi & Fen Bilgisi Öğrt. & 3 & 18 \\
\hline Çevre Kimyası & Fen Bilgisi Öğrt. & 4 & 26 \\
\hline Çevre Eğitimi & Sinıf Öğretmenliği & 1 & 44 \\
\hline Cevre Eğitimi & Sosyal Bilg. Öğrt. & 1 & 24 \\
\hline
\end{tabular}

Eğitim fakültelerinde mezun olan öğrenciler meslek hayatlarında öğretmenlik yapmaya aday insanlardır. Öğretmen adaylarının meslek hayatları da düşünüldüğü̈nde çevre sorunlarına duyarlı ve çevre sorunları hakkında sebep sonuç ilişkisi kurup çözüm geliştirebilen niteliklerle yetiştirilmesi eğitim kurumlarında çevre eğitiminin sürdürülebilirliği açısından önemlidir. Nitekim Muş Alparslan Üniversitesi faaliyet raporunda ülkemizin gelişmiş ülkeler arasındaki yerini alabilmesi için ihtiyacı olan demokratik ve etik değerlere saygıll, çevre, ülke ve dünya sorunlarına duyarlı, akademisyen ve öğretmenler yetiştirilmesi hedefi (Faaliyet Raporu, 2019:3) ifade edilmektedir. Çevre hususunda bu hedeflere ulaşmak için müfredatta çevre temalı derslerin sayıları artırılmalı, hiç çevre dersi olmayan bölümlere çevre temalı dersler eklenmelidir. Bu şekilde öğrencilerin en azından eğitim öğretim hayatında çevre dersi alması sağlanmalıdır. Eğitim fakültesinin sahip olduğu bulgular hiç çevre dersi almayacak öğrencilerin sayısının bu dersi alacaklara 
nispeten çok fazla olduğuna işaret ediyor. $\mathrm{Bu}$ durumda çevresine duyarlı çevresel sorunların farkında öğretmen adaylarının yetiştirilmesi hedefine ulaşılamayacaktır.

Diğer fakültelerden mezun olacak öğrencilerin de çevre eğitimi alanında yeterli bir donanıma, bilgiye ve kaliteye sahip olması gerektiğini hatırda tutarak belirtmek gerekirse öğretmenlerin aynı zamanda öğrenci yetiştirecekleri göz önüne alındığında öğretmenlerin çevre farkındalığına sahip olarak yetiştirilmesi önemli olmaktadır. Çünkü öğretmenler, yetiştirecekleri bireyleri çevresel sorunlara duyarlı, sorunların çözümünde sorumluluk sahibi ve çevreye karşı duyarlı bir şekilde yetiştirdiklerinde var olan çevresel sorunların çözümünde önemli bir mesafe alınmış olacaktır. Öğretmenlerin çevre eğitimine yönelik algıları, çevre eğitiminin belirtilen hedeflere ulaşılmasında belirleyici bir rol oynamaktadır (Demircioğlu vd, 2015:171). Çevre eğitimi verecek öğretmenlerin yükseköğretim düzeyinde iyi bir eğitim alması gerektiği ön plana çıkmaktadır. Ancak duyarlı ve bilinçli öğretmenler çevre konusunda öğrencilere gerekli bilinci ve sorumluluğu kazandırabilirler (Erökten ve Durkan, 2010:1863). Yapılan bazı araştırmalar öğretmenlerin çevre ve çevre koruma ile ilgili konulara çok sık değinemedikleri; öğretmenlerin, öğretmen adaylarının ve diğer üniversite öğrencilerinin çevre sorunlarına yönelik bilgi düzeylerinde yüzeysel bilgiye sahip olduklarını (Yücel ve Morgil, 1999: 81; Fettahlığlu, 2018: 421; Kiper vd, 2017:121; Erten, 2005: 93; Demircioğlu vd., 2015:183; Erkol ve Erbasan, 2018: 819, Selim vd, 2011:154; Akbaş ve Kırımlı, 2019:1247) ortaya koymaktadır. Benzer bir sonuç eğitim fakültesinden mezun olacak öğrencilerin çoğunun hiçbir çevre dersi almayacak olması durumu göz önünde bulundurulduğunda Muş Alparslan Üniversitesi mezunu birçok öğretmen adayları için de geçerli olacağı açıktır.

Lisans ve ön lisans dişında çalışmada enstitünün durumu da incelenmiştir. Muş Alparslan Üniversitesi'nde Fen Bilimleri ve Sosyal Bilimler Enstitüsü olarak iki enstitü bulunmaktadır. ${ }^{14}$ Her iki enstitüde aşağıdaki tablo 6 ve 7'de görüldüğü gibi 2019-2020 eğitim öğretim yılında kayıtlı toplamda 461 öğrenci görülmektedir. Fen Bilimleri Enstitüsünün sahip olduğu Matematik ve STEM Eğitimi dışında diğer anabilim dallarının alanları doğrudan çevreyle ilgilidir. Nükleer Enerji ve Enerji Sistemleri ve Gida Güvenliği dalları çevre eğitimi ve bilinci ekseninde hayati bir yere sahiptir. Çevre sorunları bağlamında üzerinde tartışılan önemli konular içerisinde yer alan gıda güvenliği, enerji sistemleri ve nükleer enerjinin üniversitenin yüksek lisans düzeyinde programlarında var olması çevre bilinci ve sorunları karşısında bilimsel bilginin de üretilmesi açısından önemlidir. Bununla birlikte Biyoloji, Fen Bilgisi, Kimya, Fizik, Matematik ve STEM Eğitimi dallarında öğrencilerin çevre bilincine katkısı olacak derslerin olmaması çevre eğitimi açısından dez-avantaj olarak durmaktadır.

\begin{tabular}{|l|l|l|l|l|}
\hline $\begin{array}{l}\text { Tablo 6: Muş Alparslan Üniversitesi Sosyal Bilimler Enstitüsü } \\
\text { Verileri }\end{array}$ \\
\hline Anabilim Dah & $\begin{array}{l}\text { Tezsiz } \\
\text { YL }\end{array}$ & $\begin{array}{l}\text { Tezli Yük. } \\
\text { Lis. }\end{array}$ & Doktora & $\begin{array}{l}\text { Cevre } \\
\text { Dersleri }\end{array}$ \\
\hline $\begin{array}{l}\text { Beden Eğt ve Spor } \\
\text { Eğt. }\end{array}$ & 51 & 51 & 54 & 3 \\
\hline Felsefe & - & 24 & 24 & - \\
\hline $\begin{array}{l}\text { Temel İslam } \\
\text { Bilimler }\end{array}$ & 74 & 112 & 21 & - \\
\hline $\begin{array}{l}\text { Türk Dili ve } \\
\text { Edebivatı }\end{array}$ & - & 40 & - & - \\
\hline $\begin{array}{l}\text { Kürt Dili ve } \\
\text { Kültürü }\end{array}$ & 28 & 30 & - & - \\
\hline Tarih ve & 15 & 80 & - & - \\
\hline $\begin{array}{l}\text { Manevi Dan. } \\
\text { Reh. }\end{array}$ & - & - & - \\
\hline $\begin{array}{l}\text { Siy. Bil. ve Kamu } \\
\text { Yön. }\end{array}$ & 23 & 33 & - & 2 \\
\hline Toplam & $\mathbf{1 9 1}$ & $\mathbf{3 7 0}$ & $\mathbf{9 9}$ & $\mathbf{5}$ \\
\hline
\end{tabular}

Tablo 6'da Sosyal Bilimler Enstitüsü'ne bakıldığında enstitünün çevre eğitimi açısından yeterli bir müfredata sahip olmadığı görülmektedir. Sosyal Bilimler Enstitüsünde 2019-2020 eğitim öğretim yılında kayıtlı 353 öğrenci bulunmaktadır. 660 seçmeli/zorunlu toplam ders içerisinde 5 adet çevre temalı ders bulunmaktadır. ${ }^{15}$

Felsefe Ana Bilim Dalı'nda “Çevre Felsefe” önemli olmasına rağmen yüksek lisans programında böyle bir ders bulunmamaktadır. Aynı şekilde Siyaset Bilimi ve Kamu Yönetimi Anabilim Dalı'nda "Kentleşme ve Çevre Sorunları/Politikaları" temel bilim dalı olmasına rağmen toplamda 55 ders arasinda müfredatta birer ders bulunmaktadır. Ders müfredatında yer alan 660 seçmeli veya zorunlu ders arasında Sosyal Bilimler Enstitüsü'nün sahip olduğu çevre temalı ders sayısı 5 olarak görülmektedir. Bu dersler ise Beden Eğitimi Programı ile Siyaset Bilimi ve Kamu Yönetimi Programındadır. Yani sosyal bilimler enstitüsünün sahip olduğu diğer dallarda okuyan öğrenciler her hangi bir çevre dersi almayacaktır.

\begin{tabular}{|l|l|l|l|l|}
\hline \multicolumn{5}{|c|}{ Tablo 7: Muș Alparslan Üniversitesi Fen Bilimler Enstitüsü Verileri } \\
\hline Anabilim Dah & $\begin{array}{l}\text { Tezsiz } \\
\text { YL }\end{array}$ & $\begin{array}{l}\text { Tezli Yük. } \\
\text { Lis. }\end{array}$ & Doktora & $\begin{array}{l}\text { Cevre } \\
\text { Dersleri }\end{array}$ \\
\hline Matematik & - & 80 & 40 & - \\
\hline Biyoloji & - & 40 & - & - \\
\hline Fen Bilgisi Eğitimi & - & 14 & - & - \\
\hline Fizik & - & 35 & - & - \\
\hline Gıda Güvenliği & - & 16 & - & - \\
\hline Kimya & - & 26 & - & - \\
\hline $\begin{array}{l}\text { Nük. Enerji ve Enerji } \\
\text { Sis. }\end{array}$ & - & 36 & - & - \\
\hline STEM Eğitimi & 10 & - & - & - \\
\hline Toplam & $\mathbf{1 0}$ & $\mathbf{2 4 7}$ & $\mathbf{4 0}$ & - \\
\hline
\end{tabular}

Türkiye yükseköğretiminde gözlendiği gibi Kentleşme ve Çevre Sorunları Siyaset Bilimi ve Kamu Yönetimi Bölümünün 3 ana bilim dallarından birisi olarak kabul edilmektedir. Ancak Tablo 6'da görüldüğü gibi yüksek lisans ders müfredatı içerisinde çevre derslerinin dengeli bir ağırlığı bulunmamaktadır. ${ }^{16} \mathrm{Bu}$ durum sadece çevre eğitimi

\footnotetext{
${ }^{15} \mathrm{Bu}$ derslerden üç tanesi birer olmak üzere Beden Eğitimi ve Spor Eğitimi alanının Tezsiz Yüksek Lisans, Tezli Yüksek Lisans ve Doktora dallarındadır. 2 tanesi ise Siyaset Bilimi ve Kamu Yönetimi Anabilim Dalı'nın Tezli ve Tezsiz Yüksek Lisans bölümlerindedir.
}

\footnotetext{
${ }^{16}$ Aynı sorunsal Siyaset Bilimi ve Kamu Yönetimi Lisans Bölümü için de geçerlidir. Yani Kentleşme ve Çevre Politikaları lisans programında temel

${ }^{14}$ Enstitülerin danışmanlık, uzmanlık ve seminer gibi dersler dışında zorunlu ve seçmeli derslere sadece bakılmıştır.
} 
açısından değil; aynı zamanda bölümün temel bir birleşimi olan kentleşme ve çevre sorunları/politikaları anabilim dalının eksik kalması sonucunu da getirecektir.

Çevre temalı derslerin var olması çevre eğitimi konusunda önemli olmakla beraber bu derslerin uygun pedagojik yöntemle verilmesi ve bu dersi veren akademisyenlerin alanında uzman ve alanla ilgili çalışmalarının olması da gereklidir. Yapılan bazı alan araştırmalarına göre çevre bilgisi noktasında öğrenci ve memurlardan daha iyi düzeyde olduğu görülen akademik personelin bu bilgileri uygulamaya geçirme noktasında yeterli olmadığ görülmektedir (Cansaran, 2014:72-73; Erten, 2005: 95-97, Esen, 2018:177; Demircioğlu vd., 2015:183, Gül ve diğerleri, 2018:25; Atik ve Doğan, 2019:10; Erten, 2005: 93; Demircioğlu vd., 2015:178; Aksu vd, 2012:50). Yani sahip olunan çevre bilgisinin davranış ve tutum geliştirmeye dönüştürülmesinde eksiklikleri görülmektedir. Diğer taraftan çevre eğitimi dersi alıp almayan öğrenciler arasında anlamlı bir farkın olmadığı sonucuna varıp çevre eğitimi derslerinin yetersiz olduğu da ortaya konulmaktadır (Oğuza vd 2011:38). Bu nedenle çevre eğitimi dersinin çevre alanında çalışmaları olan akademisyenler tarafindan çevreci bir tutum geliştirilmesine yarayacak uygun pedagojik yöntemlerle verilmesi önemli görülmektedir. $\mathrm{Bu}$ sorunsal ekseninde Muş Alparslan Üniversitesine bakıldığında okutulan çevre temalı derslerin çevre alanında çalışmaları olan ve çevre eğitimiyle ilgili uzmanlıkları olan akademisyenler tarafindan açılan çoğu derslerin okutulduğu görülmektedir. Bununla birlikte çevre alanıyla ilgili uzmanlık ve çalışmaları olmayan öğretim elemanları tarafından verilen derslerin olduğu da görülmektedir. Çevre derslerine çalışma alanı arasında çevrenin olmadığı öğretim elemanları tarafindan okutulmaması yani çevre eğitimi derslerinin amacına ulaşması için alanla ilgili öğretim elemanları tarafindan derslerin okutulması tercih edilmelidir. Zira yukarıda ifade edildiği gibi bu dersleri alan öğrencilerle almayan öğrencilerin çevre bilgisi konusunda anlamlı bir farkın olmamasının en önemli sebebi okutulan çevre derslerinin etkinliği ve verimliliğiyle doğrudan ilişkili olsa gerek.

\section{Sonuç}

Çevrenin korunması ve gelecek kuşaklara yaşanabilir bir dünya bırakılabilmesi bütün insanlar için bir sorumluluk olarak durmaktadır. Gelecek kuşakların haklarını gözeterek yaşanabilir bir dünya için çevre eğitimi önemli bir gerekliliktir. $\mathrm{Bu}$ temelde üniversite eğitiminde çevre konusunun üzerinde daha fazla durulması gerekmektedir. Çevre bilinci ve eğitimi yükseköğretimle sınırlandırılmamalıdır. Bununla beraber çevre bilinci ve eğitimi konusunda yükseköğretimin önemli bir rolü olduğunu da unutmamak gerekir. Çevre konusunda merkezi planlamalar, kanunlar ve hükümet politikaları önemli olmakla beraber çevresel değerlerin korunmasını salt bu kurumlara yüklemek eksik olacaktır. $\mathrm{Bu}$ eksikliği tamamlamak için eğitim kurumları aracılığıyla çevre bilinci gelişmiş, çevresel duyarlılığı olan insan profili oluşturulmalıdır.
Muş Alparslan Üniversitesi ders müfredatları, ders havuzları, açılan dersler ve bu dersleri alan öğrenci sayıları incelendiğinde elde edilen sonuçlar çevre eğitimi konusunda üniversitenin ders müfredatlarının geliştirilmesi gerektiğine işaret etmektedir. Öğrencilerde çevresel bilinç geliştirecek her hangi bir derse sahip olmayan birimlerin olması çevre bilinci açısından önemli bir eksikliktir. Mevcut ders havuzuna bakıldığında öğretmen adayları da dahil öğrencilerin yüzde doksanından fazlası her hangi bir çevre temalı ders almadan mezun olacaklardır. Bu durum çevre eğitimi konusunda üniversitenin anlamlı bir rolü yerine getirmesini zorlaştırmaktadır. Seçmeli bile olsa üniversitenin ders müfredatına öğrencilerin güncel çevresel sorunları görecek, alan bilgilerini çevresel sorunların çözümüyle ilişkilendirebilecek, çevresel sorunlar karşısında tutum ve davranışta bulunmasını sağlayacak bir muhtevayla ders müfredatlarına çevre bilinci eğitimine katkısı olacak dersler eklenmelidir. Ve bu dersler çevre konusunda uzmanlıkları veya çalışmaları olan öğretim elemanları tarafindan okutulmalidir.

Çevre bilinci eğitiminin amacına ulaşması için üniversitenin güçlü yönleri de bulunmaktadır. Üniversitenin Uygulamalı Bilimler Fakültesi ve Fen Bilimleri Enstitüsünün sahip olduğu ders müfredatı alan itibariyle çevre bilinci eğitiminde önemli bir yere sahiptir. Üniversitenin Uygulamalı Bilimler Fakültesi ve Fen Bilimleri Enstitüsü'ünün sahip olduğu çevre temalı dersleri diğer birimlerin de alabilmesinin önü açılabilir. Bununla birlikte bu fakülte ve enstitüde alan bilgisinin güncel çevresel sorunlarla ilişki kurmaya yarayacak, öğrencilerde çevresel tutum ve davranış geliştirmesini sağlayacak seçmeli veya zorunlu dersler eklenmelidir.

Enstitüler, Fakülteler ve Bölümler arasında öğretim elemanı görevlendirilmesi esnekleştirilip ve öğrencilerin farklı birimlerden ders seçebilme imkânı sağlanıp üniversitede çevre eğitimi güçlendirilmelidir. $\mathrm{Bu}$, çevre eğitiminin sahip olduğu disiplinler arası niteliğine de uygun olacaktır.

Başta Sosyal Bilimler Enstitüsü ve eğitim fakültesi olmak üzere bir bütün olarak üniversitede çevresel eğitimin geliştirilmesi perspektifiyle ders müfredatlarının değiştirilmesi ve geliştirilmesi gerekmektedir. Aynı şekilde sosyal bilimler alanında Siyaset Bilimi ve Kamu yönetimi, Felsefe ve sosyoloji gibi bölümlerde çevre önemli bir yer tutmaktadır. Ancak bahsi edilen bölümlerde fakülte ve enstitü düzeyinde yeterli ve dengeli bir çevre müfredatı bulunmamaktadır. $\mathrm{Bu}$ birimlerde çevre bilim alanı güçlendirilmelidir.

Günümüzde meydana gelen insan kaynaklı çevre sorunlarının aşılabilmesi için bireylerin çevreye karşı duyarlılıklarının ve farkındalılıklarının arttırılması gerekmektedir. Bunun sağlanabilmesi etkin bir çevre eğitimiyle mümkün olacaktır. 


\section{Kaynakça}

Acar, A., Nemutlu, E., Gürhan, G., \& Liman, V. (2004). Hacettepe Üniversitesi Eczacılık Fakültesi Araştırma Görevlilerinin İş Memnuniyeti ve Bunu Etkileyen Faktörler. Hacettepe Üniversitesi Eczacllık Fakültesi Dergisi, 24(2), 95-106.

Akbaş, İ. ve Kırımlı, E. N.(2019). Üniversite öğrencilerinin çevre duyarlılığı: ölçek geliştirme çalışması. Kastamonu Education Journal, 27(3), 1245- 1256.

Aksu, M., Temeloğlu, E., Özkaya, E., ve Gündeğer, M. (2012), Lisans Düzeyinde Turizm Eğitimi Alan Öğrencilerin Turizm ve Çevre Bilinci Üzerine Bir Araştırma, Düzce Üniversitesi Sosyal Bilimler Enstitüsü Dergisi, 2 (2):42-61.

Akyüz, E. (2015). Çevre Sorunları ve İnsan Hakları İlişkisi. Akademik Sosyal Araştırmalar Dergisi, Yll: 3, Sayl: 15, Eylül 2015, s. 427-436.

Atik, A. D. ve Doğan, Y. (20199. Üniversite Öğrencilerinin Çevre Dostu Davranışları, Muallim Rıfat Eğitim Fakültesi, 1(1): 1-21.

Bilgili, M.Y. (2015). Anayasal Bir Hak Olarak Çevre Hakkı. Çankırı Karatekin Üniversitesi Sosyal Bilimler Enstitüsü Dergisi, 6(2), 563-584.

Cansaran, D. (2014). Çevre Bilinci Düzeyini Belirlemeye Yönelik Uygulamalı Bir Çalışma: Merzifon Meslek Yüksekokulu Örneği. Aksaray Üniversitesi İktisadi ve İdari Bilimler Fakültesi Dergisi . 7(1) . 69-74.

Demircioğlu, G., Demircioğlu, H. ve Yadigaroğlu, M. (2015). Fizik, Kimya ve Biyoloji Öğretmen Adaylarının Çevre Bilinç Düzeylerinin Değerlendirilmesi. Adiyaman Üniversitesi Sosyal Bilimler Enstitüsü Dergisi Y. 8, ss: 167-193.

Erkol, M. ve Erbasan, Ö. (2018). Öğretmenlerin Çevre Eğitimi Öz-Yeterliklerinin Çeşitli Değişkenler Açısından İncelenmesi, Erzincan Üniversitesi Ĕgitim Fakültesi Dergisi, 20 (3):810-825.

Erten, S. (2005). Okul Öncesi Öğretmen Adaylarında Çevre Dostu Davranışlarının Araştırılması, Hacettepe Üniversitesi Eğitim Fakültesi Dergisi, 28: 91-100.

Esen A. ve Esen M.F. (2018). Çevre Eğitimi ve Bilinci Araştırması, Akademik Baklş Dergisi, Sayl: 65, ss: 164-178.

Erökten S. ve Durkan, N. (2010). Çevre Eğitimi Dersinin Öğrencilerin Çevreye Karşı Tutumları ve Davranışları Üzerine Etkileri. e-Journal of New World Sciences Academy Education Sciences, 1C0242, 5, (4), 1861-1867.

Faaliyet Raporu, 2019 Yılı Muş Alparslan Üniversitesi İdare Faaliyet Raporu, Strateji Geliştirme Daire Başkanlığı, Şubat - 2020.

Fettahlıŏlu, P. (2018). Algılanan Çevresel Sorunların Çevre Okuryazarlık Düzeyine Göre Analizi, Mersin Üniversitesi Eğitim Fakültesi Dergisi, 2018; 14(1): 404-425.

Gül, S., Aydoğmuş, M., Çobanoğlu, İ. H. ve Türk,H. (2018). Üniversite Öğrencilerinin Çevre
Bilinçlerinin İncelenmesi: On dokuz Mayıs Üniversitesi Örneği. Gazi Eğitim Bilimleri Dergisi (GEBD), 4 (3):13-28.

Genevie`ve M. Perron, Raymond P. Cote, John F. Duffy (2006). Improving Environmental Awareness Training İn Business. Journal of Cleaner Production, 14(6-7), 551-562.

Hamowy, R. (2003). Çevresel Hareketin Retoriği Üzerine Birtakım Mülahazalar. Yusuf Şahin (Çev.), Liberal Düşünce Dergisi bahar-yaz 2003, ss: 121-136.

Jickling, B., ve Wals, A. E. (2008). Globalization and environmental education: Looking beyond sustainable development. Journal of curriculum studies, 40(1), 1-21.

Karademir, E. (2016). Eğitim Fakültelerinin Yapılandırılması Sürecinde Öğretmen Adaylarının Çevre Bilinci ve Öz Yeterliklerinin Belirlenmesi. Eğitim ve İnsani Bilimler Dergisi, C.7,S.13, ss: 3-18.

Karataş, A. (2013). Çevre Bilincinin Geliştirilmesinde Çevre Eğitiminin Rolü Ve Niğde Üniversitesi Ĕ̈itim Fakültesi Örneği, Doktora Tezi. Ankara Üniversitesi Sosyal Bilimler Enstitüsü Sosyal Çevre Bilimleri Anabilim Dalı.

Karabıçak, M. ve Armağan, R. (2004). Çevre Sorunlarının Ortaya Çıkış Süreci, Çevre Yönetiminin Temelleri ve Ekonomik Etkileri. Süleyman Demirel Üniversitesi, IIBBF, C.9, S.2, ss:203-228.

Kiper, T., Korkut, A. Ve Topal Üstün, T. (2017). Üniversite Öğrencilerinin Çevre Duyarlılıkları Üzerine Bir Araştırma: Namık Kemal Üniversitesi Örneği, İnönü Üniversitesi Sanat ve Tasartm Dergisi, 7 (16) : 112124.

Kılıç, S. M. İnal, E. (2010), Yükseköğretimde Çevre Eğitimi Alan Ve Almayan Öğrencilerde Çevre Bilinci: Niğde Üniversitesi Örneği, Niğde Üniversitesi I.I. B.F Dergisi, C. 3, S.2, s.70-83.

Kışlalıoğlu M. ve Berkes F. (1993), Çevre ve Ekoloji, 3. Bask1, İstanbu: Remzi Kitapevi.

Konak, N.(2010). Çevre sosyolojisi: kavramsal ve teorik gelişmeler. Selçuk Unniversitesi Sosyal Bilimler Enstitüsü Dergisi, 24/2010.

Nwachukwu, M.(2014). Environmental Education and Awareness Manual. LAP LAMBERT Academic Publishing, Saarbrücken. ISBN: 978-3-659-55249-6.

Oğuza, D., Çakcı, I. ve Kavas, S. 8 2011), Yüksek Öğretimde Öğrencilerin Çevre Bilinci, SDÜ Orman Fakültesi Dergisi, C.12: 34-39.

Orr, D. W. (1992). Ecological literacy: Education and the transition to a postmodern world. Suny Press.

Öztürk, S. A. (2019). Sosyal Bilimler Ön Lisans Öğrencilerinin Çevre Duyarlılıklarının İncelenmesi, Sosyal Bilgilerde Yenilikçi Araştırmalar Dergisi, 2(1):71-79.

Roussopoulos, D. (2017). Politik Ekoloji: İklim Krizi ve Yeni Toplumsal Gündem. Fuat Dara Elhüseyni (Çev.), İstanbul:Sümer Yay. 
Rickinson, M. (2001). Learners And Learning İn Environmental Education: A Critical Review Of The Evidence, Environmental Education Research, 7(3), 207-320

Selim, S., Karakuş, N., Elkan S. ve Selim, C. (2011), Meslek Yüksekokulu Öğrencilerinin Çevre Sorunlarına İlişkin Görüş ve Tutumlarının Değerlendirilmesi: Ortaca Meslek Yüksekokulu Örneği, SDÜ Orman Fakültesi Dergisi, 12: 148-154.

Sezer, Ö. (2019). Küresel Konferanslar ve Çevre Sorunları: Çevre kalkınma ve etik açısından eleştirel bir değerlendirme. Uluslararası Asya ve Kuzey Afrika Çalışmaları Kongresi,(ICANAS 38), ss:10-15.

Sanera, M.ve Shaw, J. S. (1999). Korkular Değil Gerçekler, Vural Fuat Savaş (çev.), Ankara: Liberte Yay.

Schleicher, K. (1989). Beyond environmental education: The need for ecological awareness. International Review of Education, 35(3), 257-281.

Şahin, S.H., Ünlü, E. ve Ünlü,S. (2016). Öğretmen Adaylarının Çevre Okuryazarlık Farkındalı Düzeylerinin İncelenmesi, Education Sciences (NWSAES), 1C0655, 2016; 11(2): 82-95.

The Belgrad Charter, (1975). UNESCO-UNEP Environmental Education Newsletter, Vol.1, no. 1, January 1975.

Tilbury, D. (1995). Environmental education for sustainability: Defining the new focus of environmental education in the 1990s. Environmental education research, 1(2), 195-212.

Tbilisi Declaration (1977). Intergovernmental Conference on Environmental Education, Tbilisi (USSR) 74 - 26 October 1977.

Torunoğlu, E. (2014). "Çevre Sorunlarının nedenleri" içinde: Ü. B. Öğütüveren (Ed), Çevre Sorunları ve Politikaları, (ss.25-43), Anadolu Üniversitesi yay. Yayın No. 2554.

Tufaner, F., Tufaner, Ç. ve Dere, T. (2020). Yüksek Öğretimde Çevre Eğitiminin Yeri ve Önemi. İklim Değişikliği ve Çevre, 5, (1) 13-17.
United Nation, (1972). Report of The United Nation Conference on The Human Environment, Stockholm, 5-16 June 1972, United National Publication, A/CONF.48/14/Rev.1.

United Nation, (1987). Report of the World Commission on Environment and Development, 4 August 1987, General Assembly Forty-second session, A/42/427.

United Nation, (2002). Report of the World Summit on Sustainable Development Johannesburg, South Africa, 26 August- 4 September 2002, A/CONF.199/20.

United Nation, (1992). Report of the United Nations Conference on Environment and Development, Rio de Janeiro, 3-14 June 1992, A/CONF.151/26/Rev.l (Vol. l).

United Nation, (1997). Programme for the Further Implementation of Agenda 21, General Assembly Nineteenth special session, A/RES/S-19/2, 19 September 1997.

Ünal, S. ve Dımışkı, E. (1999). UNESCO. UNEP Himayesinde Çevre Eğitiminin Gelişimi ve Türkiye'de Ortaöğretim Çevre Eğitimi. Hacettepe Üniversitesi Ĕgitim Fakültesi Dergisi 16-17 ss: 142 $-154$.

Yıldırım, A. ve Şimşek, H. (2011). Sosyal Bilimlerde Nitel Araştırma Yöntemleri. Ankara: Seçkin Yayıncılık.

Yücel A.S. ve Morgil F. İ., (1999). Çevre Eğitiminin Geliştirilmesi, Balıkesir Üniversitesi Fen Bilimleri Enstitüsü Dergisi, 1999, C.1,S. 1, 76-89.

YÖK, (2020), Yükseköğretim Kurulu 2019 Y1lı Yükseköğretim Kurumları Sınavı Yerleştirme Sonuçları Raporu,https://www.yok.gov.tr/HaberBelgeleri/Hab er\%20\%C4\%B0\%C3\%A7erisindeki\%20Belgeler/D osyalar/2019/yks_2019_sonuc_raporu.pdf, Erişim, 09.08.2020. 